\title{
КРИТЕРИИ ФОРМИРОВАНИЯ ОТДЕЛЬНЫХ ПРОФЕССИОНАЛЬНО-ПЕДАГОГИЧЕСКИХ УМЕНИЙ
}

\section{CRITERIA FOR THE FORMATION OF INDIVIDUAL PROFESSIONAL AND PEDAGOGICAL SKILLS}

\section{J. Kravchenko}

Summary: The criteria for the formation of individual professional and pedagogical skills are highlighted. Their features are theoretically substantiated and their characteristics are given. Test questions have been developed for identifying criteria features. Tasks have been prepared to determine the ownership of pedagogical techniques and pedagogical technologies.

Keywords: criteria, signs, pedagogical tasks, teachers in the future, skills formation.

\author{
Кравченко Юлия Михайловна \\ К.n.н., дочент, ФГАОУ ВО «Севастопольский \\ государственный университет», г. Севастополь. \\ ulkrav@mail.ru
}

Аннотация: Выделены критерии формирования отдельных профессионально-педагогических умений. Теоретически обоснованы их признаки и даны их характеристики. Разработаны контрольные вопросы для выявления признаков критериев. Подготовлены задания для определения владения педагогической техникой и педагогическими технологиями.

Ключевые слова: критерии, признаки, педагогические задачи, будущие учителя, формирование умений.

решать педагогические задачи .

Цель данной статьи состоит в теоретическом обосновании выделенных нами критериев и признаков формирования умений профессионально решать педагогические задачи при подготовке педагогических кадров.

Показателями формирования умений, как правило, являются определенные действия и их сочетание, выполнение которых согласуется с поставленными в ходе учебно-воспитательного процесса задачами. Г.А. Атанов отмечает, что умения имеют сложную структуру, могут быть составными, то есть представлять собой набор более простых [1, с. 57]. В работе "Дидактика современной школы" под редакцией В.А. Онищука утверждается, что умения состоят из знаний основ действия (понятий, законов, теорий), способов их выполнения, последовательности, навыков обращения с оборудованием, опыта выполнения на практике аналогичных действий, а также элементов творческого подхода [2, с. 81]. Следовательно, умения решать педагогические задачи имеет структуру из ряда составных частей. В свою очередь, П.И. Пидкасистый [3, с. 361] отмечает, что все выполняемые действия имеют общие элементы, реализация которых позволит воспроизвести каждое конкретное умение. Выделив эти элементы, можно определить критерии формирования умений.

Теоретический анализ проблемы исследования в ходе формирования умений профессионально решать педагогические задачи при подготовке будущих учителей дал нам основания предполагать реализацию двух 
позиций: теоретической и практической. На основании этого утверждения, а также путем выделения основных этапов процесса решения педагогических задач, нами было выделено три основных критерия формирования умений профессионально решать педагогические задачи:

1 - теоретической осведомленности в области педагогических задач;

2 - педагогической грамотности в области решения педагогических задач;

3 - практического мастерства.

Первый критерий определяет теоретическую готовность будущих учителей, второй критерий характеризует связь теоретической и практической готовности, а третий критерий определяет уровень их практической подготовленности.

К признакам критерия теоретической осведомленности в области педагогических задач относятся:

- знание теоретических основ, основных определений, классификаций педагогических задач и ситуаций;

- знания о роли педагогических ситуаций и задач при подготовке будущих учителей;

- знание подходов к оцениванию качества решений педагогических задач.

Признаками критерия педагогической грамотности в области решения педагогических задач являются:

- знания в области педагогического общения, культуры поведения учителя, педагогического мастерства;

- умение владеть педагогической техникой и педагогическими технологиями, экспрессивными средствами общения;

- умение анализировать педагогические ситуации, как составляющие профессионализма, профессиональной компетентности (одного из элементов педагогического мастерства);

- умение осознавать проблему и выделять задачу из педагогической ситуации.

Критерий практического мастерства характеризуется следующими признаками:

- умение моделировать, планировать практическую реализацию решения педагогических задач, построение алгоритма определенных действий;

- умение реализовывать намеченный комплекс действий по решению педагогических задач;

- умение осуществлять самоанализ результатов педагогических действий, сопоставляя эти результаты с поставленной педагогической целью.

Опираясь на педагогические исследования, связанные с педагогическими ситуациями и решением педа- гогических задач, мы разработали методику формирования умений профессионально решать педагогические задачи.

Степень проявления этих критериев и показателей свидетельствуют об уровне сформированности умений решать педагогические задачи в системе подготовки будущих учителей.

В качестве примеров вопросов и заданий для определения уровня сформированности признаков критериев формирования умений профессионально решать педагогические задачи можно привести следующие задания.

Контрольные вопросы для выявления признаков критерия теоретической осведомленности в области педагогических задач, а именно - знания теоретических основ, основных определений, классификаций педагогических задач и ситуаций (первый признак первого критерия формирования умений профессионально решать педагогические задачи).

1. Что такое педагогическая ситуация?

2. Как Вы понимаете, что такое педагогическая задача?

3. Какие классификации педагогических ситуаций и задач Вы знаете?

4. Назовите ученых, которые занимались проблемой решения педагогических задач.

Темы беседы со студентами для выявления признака критерия теоретической осведомленности в области педагогических задач - знания о роли педагогических ситуаций и задач при подготовке будущих учителей (второй признак первого критерия формирования умений профессионально решать педагогические задачи):

1. Как Вы считаете, целесообразно ли применять решение педагогических задач в ходе подготовки будущих учителей?

2. Как часто Вы сталкивались в ходе своей педагогической практики с решением педагогических задач?

3. Как часто преподаватели, которые Вас обучают, в ходе Ваших занятий сталкиваются с решением педагогических задач?

4. Как Вы думаете, преподаватели в ходе Вашего обучения принимают спонтанные решения или заранее продумывают их, опираясь на свой педагогический опыт?

Контрольные вопросы для выявления знания подходов к оцениванию качества решений педагогических задач (третий признак первого критерия формирования умений профессионально решать педагогические задачи):

1. По какому принципу Вы бы предложили оцени- 
вать возможные решения педагогических задач? Перечислите основные критерии.

2. Как Вы считаете, возможна ли абсолютная объективность в оценивании выбранных решений?

Контрольные вопросы по признаку критерия педагогической грамотности в области решения педагогических задач - знаниям в области педагогического общения, культуры поведения учителя, педагогического мастерства (первый признак второго критерия формирования умений профессионально решать педагогические задачи).

1. Что Вы понимаете под педагогическим мастерством, назовите составляющие его элементы?

2. Какие уровни педагогического общения Вы знаете?

3. Какие стили педагогического общения Вы знаете?

4. Перечислите известные Вам условия эффективного общения.

5. Что Вы понимаете под педагогической культурой?

Задания для определения владения педагогической техникой и педагогическими технологиями, экспрессивными средствами общения (второй признак второго критерия формирования умений профессионально решать педагогические задачи).

\section{Упражнение 1. "Задуманное слово"}

Группа делится на две подгруппы. Каждая задумывает слово, имеющее отношение к учебно-воспитательному процессу или связанное с изучаемой темой. Члены одной подгруппы "представляют" это слово другой подгруппе. Ее участники имеют право называть варианты ответов, а демонстраторы невербально соглашаются или не соглашаются с ними.

Упражнения подобного вида одновременно с проверкой уровня владения экспрессивными средствами общения проверяет теоретические знания.

\section{Упражнение 2. "Дискуссия"}

Преподаватель задает дискуссионную тему. Например: "Надо ли при подготовке будущих учителей решать педагогические задачи, и если да, то почему". Участники делятся на две группы: 1-я группа - условно согласные с утверждением (придерживающиеся одной точки зрения), 2-я группа - придерживается другой точки зрения. Ведется дискуссия по заданной теме.

\section{Упражнение 3 "Воспроизведи интонацию"}

Преподаватель произносит фразу с характерной интонацией, затем каждый студент должен повторить эту интонацию, но произнести другую фразу. Варианты фраз:
- Здравствуйте!

- Откройте тетради!

- На первый вопрос ответит...

В качестве варианта этого упражнения может быть повторение студентами фразы произнесенной преподавателем, но с другой интонацией.

Педагогические ситуации и задачи для определения умения анализировать педагогические ситуации, как составляющую профессионализма, профессиональной компетентности (третий признак второго критерия формирования умений профессионально решать педагогические задачи), умения осознавать проблему и выделять задачу из педагогической ситуации.

\section{Задача 1.}

Звонок к уроку. Учитель физики входит в класс и наблюдает следующую картину: по классу летает воробей, ученики стараются его поймать.

Задание.

1. Проанализировать ситуацию.

2. Что должен сделать учитель в этой ситуации.

Задача 2.

В школьном курсе физики учащимся трудно запомнить название цветов, на которые раскладывается спектр света, а также порядок их размещения. Поэтому учащимся предлагается запомнить такое выражение: "Каждый охотник желает знать, где сидит фазан".

Задание.

1. В чем состоит суть такого приема?

2. Проанализируйте его суть с психологической точки зрения.

Тестовые задания для выявления умение моделировать, планировать практическую реализацию решения педагогических задач, построение алгоритма воспроизведения действий (первый признак третьего критерия формирования умений профессионально решать педагогические задачи - практического мастерства).

Если на Ваших занятиях возникнет педагогическая ситуация, то Вы:

а) никак не отреагируете,

б) адаптируете готовое решение под конкретную ситуацию,

в) придумаете свое собственное решения для выхода из этой ситуации.

Ситуации для деловых игр по определению уровня сформированности умений реализовывать намеченный 
комплекс действий по решению педагогических задач и осуществлять самоанализ результатов действий, сопоставляя эти результаты с поставленной педагогической целью (второй и третий признак третьего критерия формирования умений профессионально решать педагогические задачи).

\section{Ситуация 1.}

Новый учитель рисования входит в класс. Ученики, как обычно, проверяют реакцию нового учителя. Когда новый учитель вошел в класс, то по тишине в классе и взглядам учащихся понял, что надо быть готовым к неожиданностям. Неожиданно с одной из парт встал подросток и громко закричал "Разрешите представиться. Меня зовут Шевченко, а Вас как?". Учитель был психологически готов к нестандартному приему со стороны учеников, но не к такому, разумеется.

\section{Ситуация 2.}

Учитель географии пришел на урок в 8-й класс и заметил, что все географические карты висят вверх ногами. Какова должна быть реакция учителя?

Таким образом, посредством использования вышеперечисленных критериев формирования умений решать педагогические задачи и их признаков можно определить уровень психолого-педагогической подготовки педагогических кадров и в дальнейшем уделить особое внимание тем разделам формирования умений, которые вызывают особое затруднение.

\section{ЛИТЕРАТУРА}

1. Атанов Г.О. Діяльнісний підхід у навчанні. - Донецьк: “ЕАИ-пресс", 2001. - 160 с.

2. Дидактика современной школы: Пособие для учителей/ Б.С. Кобзарь, Г.Ф. Кумарина, Ю.А. Кусый и др.; Под ред. В.А. Онищука. - К.: Рад. шк., 1987. $351 \mathrm{c}$.

3. Педагогика: Учеб. пособие для студентов пед. вузов и пед колледжей/ Под ред. П.И. Пидкасистого. - М.: Пед. о-во России, 1998. - 640с.

$$
\text { (c) Кравченко Юлия Михайловна (ulkrav@mail.ru). }
$$

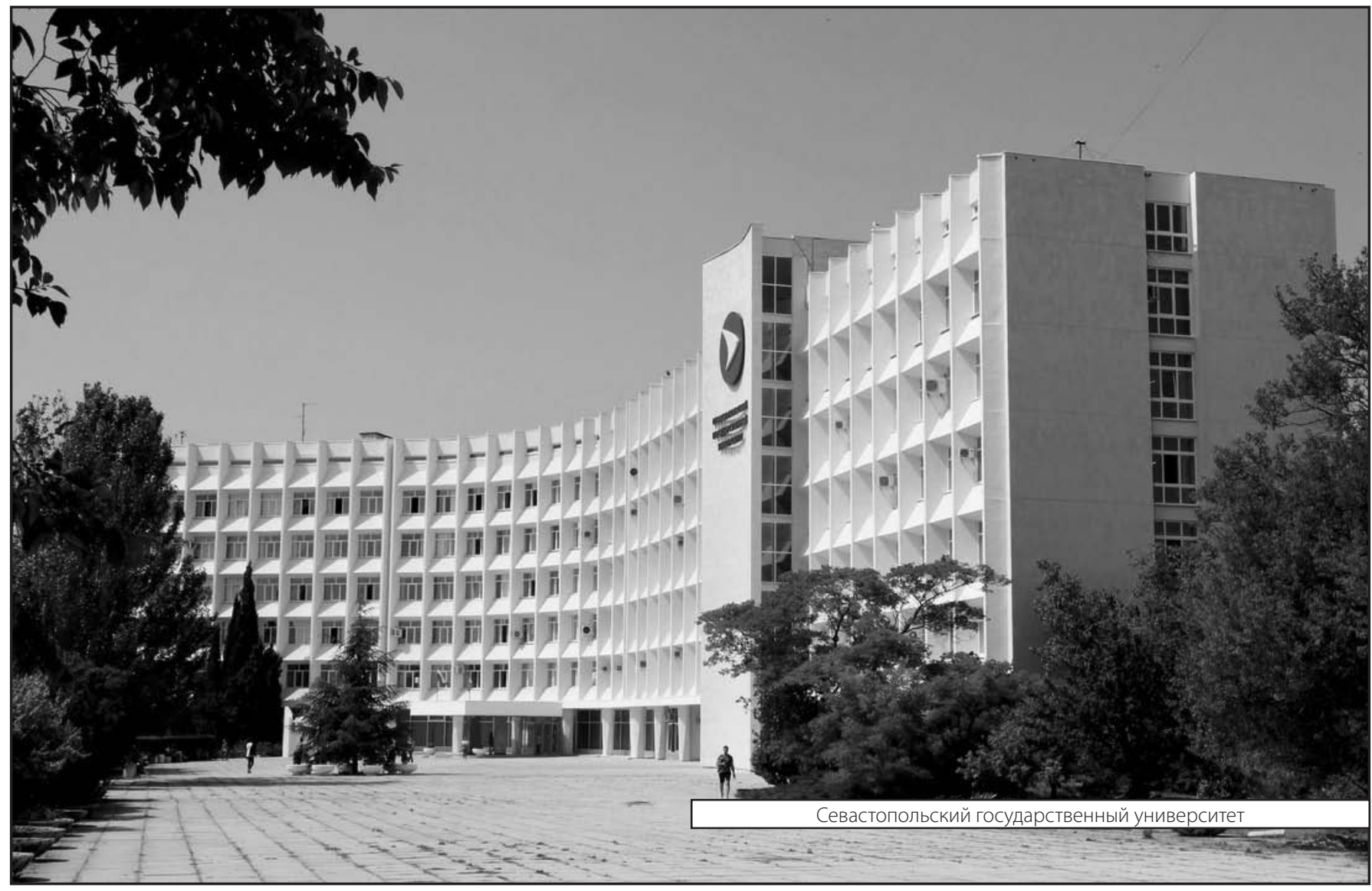

